\title{
Persepsi Masyarakat Sekitar Terhadap Corporate Social Responsibility Berlandaskan Konsep Tri Hita Karana Pada The Kayon Resort Ubud
}

\author{
Ni Kadek Eva Yanti ${ }^{1}$, I Gusti Ayu Intan Saputra Rini ${ }^{2}$, Ni Nyoman Sri Rahayu Damayanti ${ }^{3}$ dan Ni Made Satya Utami ${ }^{4}$

\section{1,2,3. Fakultas Ekonomi dan Bisnis Universitas Warmadewa} \\ 4. Fakultas Ekonomi dan Bisnis Universitas Mahasaraswati Denpasar \\ *intansaputrarini@warmadewa.ac.id
}

How to cite (in APA style):

Yanti, N, K, E, Y., Rini, I, G, A, I, S., Damayanti, N, N, S, R., Utami, N, M, S. (2020). Persepsi Masyarakat Sekitar Terhadap Corporate Social Responsibility Berlandaskan Konsep Tri Hita Karana Pada The Kayon Resort Ubud. 19 (2), pp.108-113. https://doi.org/10.22225/we.19.2.2368.108-113

\begin{abstract}
This study aims to describe the implementation of Corpotare Social Responsibility and community perceptions based on the Tri Hita Karana concept at The Kayon Resort Ubud, which is measured based on the Pawongan, Palemahan, and Parahyangan variables. This research was conducted at The Kayon Resort Ubud. The number of samples used in this study were 100 people as respondents. Data collection was carried out by distributing questionnaires and interviews. Data analysis in this study uses qualitative data analysis techniques and quantitative data using a combination method (mix method). The results of this study indicate that the implementation of Corpotare Social Responsibility and community perceptions based on the Tri Hita Karana concept at The Kayon Resort Ubud are assessed based on Pawongan, Palemahan, and Parahyangan variables that have been done well. Based on the results of the analysis, The Kayon Resort Ubud hotel must maintain and enhance the Corporate Social Responsibility program based on the Tri Hita Karana concept optimally.
\end{abstract}

Keywords: Pawongan; Palemahan; Parahyangan

Abstrak

Penelitian ini bertujuan untuk mendeskripsikan implementasi Corpotare Social Responsibility dan persepsi masyarakat berlandaskan konsep Tri Hita Karana pada The Kayon Resort Ubud yang diukur berdasarkan variabel Pawongan, Palemahan, dan Parahyangan. Penelitian ini dilakukan pada The Kayon Resort Ubud. Jumlah sampel yang digunakan dalam penelitian ini adalah 100 orang sebagai responden. Pengumpulan data dilakukan dengan penyebaran kuisioner dan wawancara. Analisis data dalam penelitian ini menggunakan teknik analisis data kualitatif dan data kuantitatif dengan menggunakan metode kombinasi (mix method). Hasil dari penelitian ini menunjukan bahwa implementasi Corpotare Social Responsibility dan persepsi masyarakat berlandaskan konsep Tri Hita Karana pada The Kayon Resort Ubud yang dinilai berdasarkan variabel Pawongan, Palemahan, dan Parahyangan sudah dilakukan dengan baik. Berdasarkan hasil analisis tersebut maka pihak hotel The Kayon Resort Ubud harus mempertahankan dan meningkatkan program Corporate Social Responsibility yang berlandaskan konsep Tri Hita Karana secara optimal.

Kata Kunci: Pawongan; Palemahan; Parahyangan

\section{PENDAHULUAN}

Industri pariwisata di Bali menjadi salah satu peluang usaha yang sangat potensial mengingat pulau Bali memiliki keindahan alam, keragaman budaya serta keunikan adat istiadat secara alami sehingga para wisatawan pun tertarik mengunjungi pulau Bali. Industri pariwisata menjadi salah satu tonggak perkembangan bisnis industri perhotelan di Bali. Kondisi industri pariwisata dan perhotelan di Bali tetap stabil, walaupun perkembangan industri perhotelan mengalami fluktuasi dari perkembangan yang terjadi di dunia pariwisata. Wakil Gubernur (Wagub) Bali Tjokorda Oka Artha Ardana Sukawati menyatakan bahwa, pariwisata Bali yang berlangsung sejak lama sudah diterima dan mendatangkan wisatawan dari berbagai daerah di Indonesia dan juga berbagai negara di dunia. Ubud merupakan salah satu Kecamatan yang ada di Kabupaten Gianyar adalah daerah wisata ternama ditingkat nasional hingga dimata dunia, yang kaya akan keanekaragaman seni, adat istiadat dan budaya yang masih tetap berkembang dan lestari sampai saat ini, sehingga dikenal sebagai Kabupaten seni. 
Ketua Perhimpunan Hotel dan Restoran Indonesia (PHRI) Kabupaten Gianyar Tjokorda Gde Agung Ichiro Sukawati mengakui peningkatan kunjungan wisatawan di Ubud memberikan dampak yang signifikan terhadap pengelola usaha pariwisata di kampung turis ini. Pembangunan pariwisata di Ubud, Gianyar yang berbasis kemasyarakatan, berkelanjutan mempunyai daya saing global berdasarkan konsep Tri Hita Karana. Hotel adalah ujung tembok pariwisata dan merupakan bagian terpenting dalam pariwisata, sebab hotel menyediakan jasa kamar, makanan, hiburan, pemandangan, cindramata, investasi yang besar dan penyerapan tenaga kerja yang banyak. Karena itu hotel pantas mendapatkan perhatian khusus. Di Bali sudah ada usaha

pembinaan dan pemberian penghargaan terhadap pengembangan pariwisata khususnya hotel yang menerapkan ramah lingkungan.

Badan Pusat Statistika Provinsi Bali mencatat tingkat penghunian kamar (TPK) hotel berbintang di Pulau Dewata sepanjang Juli 2019 rata-rata mencapai $61,71 \%$ atau naik tipis 1,34 poin dibandingkan TPK bulan sebelumnya sebesar 60,37\%. Kabupaten Gianyar tercatat mencapai TPK tertinggi yaitu 66,79\% dibandingkan dengan Kabupaten lainnya. Berbagai aktivitas kepedulian terhadap lingkungan sosial dilakukan, perusahaan akan memperoleh nilai tambah di masyarakat. Program tanggung jawab sosial yang dimaksud adalah program CSR (Corporate Social Responsibility). Program- program CSR yang akan diselenggarakan perusahaan seharusnya diimplementasikan dalam proses operasional perusahaan. Apabila program CSR yang direncanakan dapat terealisasi dengan baik, maka keseimbangan lingkungan akan tetap terjaga. Konsep CSR yang memiliki tujuan menjaga lingkungan dengan melakukan tanggung jawab sosial perusahaan dapat diaplikasikan dengan konsep Tri Hita Karana. Konsep ini dikenal berasal dari kebudayaan masyarakat Bali. Tri Hita Karana merupakan filosofi pola keserasian dan keseimbangan hubungan yang harmonis.

Beberapa kajian serupa dengan penelitian sekarang ini telah dikaji sebelumnya seperti Gursoy dkk (2019), Sri Ardani \& Mahyuni (2020) dan Bardos, Ertugrul, \& Gao (2020). Gursoy dkk (2019) mengkaji tentang persepsi warga atas inisiatif tanggung jawab sosial perusahaan hotel dan dampaknya terhadap sentimen warga terhadap masyarakat dan dukungan untuk pengembangan pariwisata tambahan. Hasil penelitiaan ini menunjukkan bahwa persepsi warga tentang praktik tanggung jawab sosial hotel berkontribusi pada dukungan warga untuk pengembangan pariwisata tambahan secara langsung dan tidak langsung melalui kepuasan warga terhadap komunitas mereka. Namun, efek dimensi tanggung jawab sosial hotel ekonomi dan lingkungan terhadap komitmen masyarakat tidak signifikan. Kepuasan komunitas adalah prediktor kuat dari komitmen dan dukungan komunitas untuk pengembangan pariwisata tambahan. Temuan menawarkan implikasi penting bagi perusahaan perhotelan, perencana komunitas, serta peneliti yang tertarik. Sri Ardani \& Mahyuni (2020) dalam penelitiannya berjudul 'Penerapan Corporate Social Responsibility (CSR) dan Manfaatnya Bagi Perusahaan', hasil penelitiannya menunjukkan bahwa Toya Devasya menerapkan Corporate Social Responsibility berlandaskan Tri Hita Karana. Dimana Tri Hita Karana mengandung makna yang sudah sangat komplek karena setiap unsurnya mencerminkan hal yang perlu dilaksanakan oleh setiap perusahaan. Perusahaan memandang penerapan Corporate Social Responsibility penting dilakukan karena menjadi solusi dari dampak kegiatan bisnis yang ditimbulkan Pelaksanaan Corporate Social Responsibiliy yang dilakukan oleh perusahaan sudah dapat diterima dengan baik oleh masyarakat sekitar. Dari penerapan Corporate Social Responsibiliy ini menunjukan adanya manfaat yang dapat diterima oleh perusahaan seperti dukungan dari masyarakat dan kenyamanan saat bekerja yang dirasakan oleh karyawan. Kesadaran yang telah dimiliki perusahaan untuk menerapkan Corporate Social Responsibiliy akan memberikan dampak besar bagi perusahaan. Keharmonisan yang tercipta antara antara perusahaaan, masyarakat dan lingkungan merupakan salah satu dampak yang akan dirasakan perusahaan dalam menjalankan kegiatan bisnisnya. Keharmonisan inilah yang akan memberikan efek terhadap citra perusahaan dimata masyarakat. Perusahaan akan mendapatkan dukungan dan diakui keberadaannya di lingkungan sekitar perusahaan. Karena terjaganya hubungan yang baik dengan lingkungan sekitar, maka masyarakat pun akan dengan sukarela memberikan dukungannya terhadap Toya Devasya seperti mempromosikan keberadaan perusahaan kepada wisatawan sehingga terjadi peningkatan jumlah pengujung yang akan mempengaruhi pendapatan. Selanjutnya, hasil penelitian dari Bardos dkk (2020) dengan judul penelitian 'Corporate social responsibility, product market perception, and firm value', menunjukkan bahwa CSR secara tidak langsung meningkatkan nilai perusahaan melalui perbaikan persepsi pasar produk. Dapat disimpulkan bahwa persepsi pasar produk adalah saluran di mana CSR menciptakan nilai perusahaan. 


\section{KAJIAN PUSTAKA}

Teori Legitimasi merupakan teori yang mempelajari mengenai keadaan psikologis keberpihakan orang dan kelompok orang yang sangat peka terhadap gejala lingkungan sekitarnya baik fisik maupun non fisik (Hadi, 2011:87). Teori Stakeholder adalah semua pihak baik internal maupun eksternal yang memiliki hubungan baik bersifat mempengaruhi maupun dipengaruhi, bersifat langsung maupun tidak langsung oleh perusahaan. Stakeholder merupakan pihak eksternal maupun internal, yaitu para karyawan, masyarakat, perusahaan/lembaga pesaing, dan pemerintah. Keberadaan perusahaan sangat dipengaruhi oleh dukungan yang diberikan oleh stakeholder (Hadi, 2011:94).

Implementasi menurut KBBI (Kamus Besar Bahasa Indonesia) yaitu pelaksanaan/ penerapan. Kata implementasi tersebut berasal dari bahasa Inggris "to implement" yang artinya mengimplementasikan, dan tidak hanya sekedar aktivitas, implementasi merupakan suatu kegiatan yang direncanakan serta dilaksanakan dengan serius dan juga mengacu pada norma-norma tertentu guna mencapai tujuan kegiatan, (Alihamdan, 2017). Persepsi

Masyarakat merupakan individu yang hidup bersama dalam suatu tatanan pergaulan, yang tercipta karena individu melakukan hubungan dan interaksi dengan individu yang lainnya.

Corporate Social Responsibility (CSR) adalah suatu konsep tentang tindakan yang dilakukan oleh perusahaan sesuai kemampuan perusahaan tersebut sebagai bentuk tanggung jawab terhadap sosial atau lingkungan sekitar di mana perusahaan itu berada.

Masyarakat Hindu di Bali, kesehariannya menganut pola Tri Hita Karana yang meliputi tiga unsur yaitu hubungan manusia dengan Tuhan (Parahyangan), hubungan manusia dengan sesama manusia (Pawongan) dan hubungan manusia dengan lingkungan (Palemahan).

Berdasarkan keputusan Menparpostel No.KM 37/PW.340/MPPT-86 tentang peraturan usaha dan penggolongan hotel menyebutkan bahwa hotel adalah suatu jenis akomodasi yang mempergunakan sebagian atau seluruh bangunan untuk menyediakan jasa penginapan makanan dan minuman serta jasa penunjang lainnya bagi umum yang dikelola secara komersial. Industri perhotelan saat ini telah menjadi industri yang banyak diminati para pebisnis.

\section{METODE}

Penelitian ini dilakukan pada The Kayon Resort Ubud, yang beralamat di Banjar Kepitu, Kenderan, Tegallalang, Ubud, Gianyar, pada tahun 2018 sampai dengan 2019. Objek penelitian adalah Persepsi Masyarakat Sekitar terhadap Coporate Social Responsibility berlandaskan konsep Tri Hita Karana pada The Kayon Resort Ubud. Jenis penelitian ini menggunkan data kualitatif, data yang digunakan ada 2 jenis yaitu data kualitatif dan data kuantitatif dengan menggunakan metode kombinasi (mix method). Populasi dalam penelitian ini terdiri dari, sebagai berikut:

Informan internal Hotel, yaitu: Karyawan atau pegawai.

Informan eksternal Hotel, yaitu: Pemuka masyarakat dan masyarakat sekitar hotel.

Metode penentuan sampel untuk informan hotel seperti Divisi Human Resource Department dan Divisi Finance The Kayon Resort Ubud adalah purposive sampling, yaitu teknik penentuan sampel dengan pertimbangan tertentu. Informan yang berasal dari pihak pemuka masyarakat Desa Kenderan diambil sampel dan menggunakan metode sensus. Informan yang berasal dari masyarakat Desa Kenderan ditentukan dengan menggunakan metode Simple

random sampling. Pemilihan simple random sampling dengan menggunakan rumus slovin yaitu, sebagai berikut:

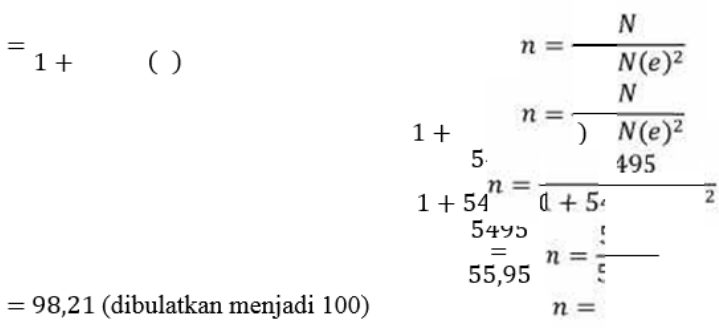


Berdasarkan perhitungan tersebut sampel yang menjadi responden dari masyarakat sekitar The Kayon Resort Ubud yaitu 100 penduduk dari seluruh total jumlah penduduk Desa Kenderan.

Tabel 1

Daftar Informan

Pada The Kayon Resort Ubud

\begin{tabular}{|c|c|}
\hline Keterangan & Jumlah Responden \\
\hline Kepala Divisi Human Resource Department & 1 \\
\hline Finance & 1 \\
\hline Pemuka Masyarakat & 11 \\
\hline Masyarakat Sekitar Hotel & 100 \\
\hline Jumlah & 113 \\
\hline
\end{tabular}

Sumber: Data diolah, 2019

Jenis data yang digunakan dalam penelitian ini yaitu, data kualitatif meliputi hasil wawancara dengan karyawan dan observasi pada The Kayon Resort Ubud. Data kuantitatif pada penelitian ini berupa alokasi dana CSR yang dipergunakan dalam kegiatan yang berhubungan dengan Tri Hita Karana.

Metode pengumpulan data dalam penelitian yaitu observasi dalam penelitian ini melakukan pengamatan langsung dalam pelaksanaan kegiatan atau aktivitas yang berhubungan dengan Corporate Social Responsibility

berlandaskan konsep Tri Hita Karana Pada The Kayon Resort Ubud. Dokumentasi data yang diperoleh dalam penelitian ini bukti pemberian dana punia ke Pura yang ada di sekitar Hotel, bukti pemberian dana bantuan kepada masyarakat kurang mampu periode 2018 sampai dengan 2019. Wawancara tidak terstruktur, yang bersifat informal sehingga dari spontanitas pewawancara dalam mengajukan pertanyaan ke informan, namun tetap harus memberikan batasan sehingga isi wawancara yang dilakukan tidaklah jauh menyimpang dari tujuan dan topik yang diharapkan. Kuesioner data yang diperoleh dari penyebaran kuesioner adalah data mengenai persepsi masyarakat terhadap Corporate Social Responsibility berlandasskan konsep Tri Hita Karana pada The Kayon Resort Ubud.

\section{HASIL DAN PEMBAHASAN}

The Kayon Resort adalah salah satu Boutique Hotel berbintang 5. Bapak I Putu Suryawan adalah selaku pemilik The Kayon Resort Ubud. The Kayon Resort berdiri diarea pinggir sungai Petanu, seluas kurang lebih 30 are, The Kayon Resort menawarkan pemandangan alam serta sungai Petanu sebagai ciri khas.

Implementasi Corporate Social Responsibility (CSR) berlandaskan konsep Tri Hita Karana pada The Kayon Resort Ubud:

\section{Pawongana}

Berikut pernyataan dari Ibu Agung Dewi selaku HRD The Kayon Resort Ubud:

The Kayon Resort Ubud memberikan 65\% peluang kerja kepada masyarakat Desa Kenderan, peluang kerja tidak hanya diberikan kepada Desa kenderan akan tetapi peluang kerja juga diberikan kepada masyarakat di luar Desa Kenderan.

\section{Palemahan}

Berikut pernyataan dari pernyataan Ibu Agung Dewi selaku HRD The Kayon Resort Ubud:

Program yang dilakukan The Kayon Resort Ubud untuk menjaga kelestarian lingkungan yaitu gotong royong mingguan dan bulanan di area sekitar hotel dan sungai bekerjasama dengan masyarakat sekitar.

Parahyangan

Berikut pernyataan dari Ibu Agung Dewi selaku HRD The Kayon Resort Ubud:

Kegiatan yang dilakukan The Kayon Resort Ubud setiap harinya yaitu sembahyang secara rutin sebelum mulai bekerja untuk memohon keselamatan dan berterimakasih atas Anugrah yang diberikan. Setiap 6 bulan sekali pada hari suci Buda Cemeng Klawu dilaksanakan piodalan di The 
Kayon Resort Ubud. Ubud

Persepsi masyarakat terhadap Corporate Social Responsibility (CSR) pada The Kayon Resort

\section{Pawongan}

The Kayon Resort Ubud selalu memberikan peluang kerja bagi masyarakat sekitar Hotel, Program CSR pada The Kayon Resort Ubud dilakukan untuk kepentingan masyarakat sekitar Hotel, memiliki program bantuan infrastruktur bagi masyarakat setempat, membantu masyarakat dalam meningkatkan mutu pendidikan, memiliki program ekonomi kemasyarakatan yang ditujukan untuk mengembangkan potensi ekonomi dan bisnis masyarakat, interaksi antara perusahaan dengan masyarakat memberikan dampak positif, mendukung kegiatan seni dan budaya dengan melakukan pertunjukan atau pementasan sendra tari dari muda mudi Desa Kenderan yang di selenggarakan pada event tertentu, memberikan bantuan dalam bidang kesehatan seperti pelayanan kesehatan gratis setiap setahun sekali kepada masyarakat Desa Kenderan, memberikan bantuan untuk korban bencana alam yang di selenggarakan oleh masyarakat Desa Kenderan, secara langsung melakukan bakti sosial kepada masyarakat Desa Kenderan yang sangat membutuhkan bantuan. Presentase yang diperoleh dari konsep pawongan yaitu 95,56\%, yang artinya konsep pawongan yang dilakukan oleh The Kayon Resort Ubud sudah baik.

\section{Palemahan}

The Kayon Resort Ubud membantu penghujauan lingkungan, The Kayon Resort Ubud menggunakan materi yang ramah lingkugan, selalu menyediakan tempat pembuangan sampah atau tong sampah untuk masyarakat sekitar, operasional hotel perusahaan tidak menimbulkan kebisingan masyarakat dan lingkungan, pelaksanaan CSR dapat meningkatkan kepedulian The Kayon Resort Ubud

terhadap kerusakan lingkungan, pemakaian energi (listrik, bahan bakar minyak, atau gas) yang berasal dari sumber energi yang baik, penggunaan air sesuai dengan kegunaannya, memiliki kesadaran apabila menghasilkan dampak buruk pada lingkungan, memberikan denda apabila melanggar peraturan mengenai lingkungan hidup, membantu memberikan dana jika ada kerusakan lingkungan akibat proses operasional. Presentase yang diperoleh dari konsep palemahan yaitu 95,85\%, yang artinya konsep palemahan yang dilakukan oleh The Kayon Resort Ubud sudah baik.

Parahyangan

Melakukan persembahyangan secara rutin setiap hari, melakukan tirta yatra dengan para karyawan atau masyarakat sekitar The Kayon Resort Ubud setiap tahunnya, program CSR pada The Kayon Resort Ubud sangat membantu dalam renovasi Pura di sekitar Hotel, selalu melakukan Yadnya dengan memberikan sumbangan saat berlangsungnya upacara agama di desa setempat, hotel secara rutin memberikan bantuan atau Dana Punia ke Pura yang ada di sekitar Hotel. Presentase yang diperoleh dari konsep parahyangan yaitu $47,41 \%$, yang artinya konsep parahyangan yang dilakukan oleh The Kayon Resort Ubud sudah baik.

\section{SIMPULAN}

Implementasi Corporate Social Responsibility (CSR) berlandaskan konsep Tri Hita Karana pada The Kayon Resort Ubud yang bersifat umum, misalnya memberikan bantuan infrastruktur kepada masyrakat yang kurang mampu, secara rutin melakukan kegiatan penghijauan di lingkungan sekitar hotel, meningkatkan kepedulian terhadap kerusakan lingkungan, selalu menjaga dan menciptakan hubungan yang harmonis antara manusia dengan Tuhan Yang Maha Esa. Kegiatan CSR The Kayon Resort Ubud sudah dilakukan dengan baik. Persepsi masyarakat sekitar terhadap CSR dinilai dari variabel Pawongan dengan 100 responden dengan persentase 95,56\%, variabel Palemahan dengan 100 responden dengan persentase $95,85 \%$, dan variabel parahyangan dengan 100 responden dengan persentase $47,41 \%$.

Meningkatkan program CSR berlandaskan konsep Tri Hita Karana secara optimal dengan membentuk team lingkungan yang memotivasi dan memberikan dorongan kepada masyarakat Desa Kenderan agar kesadaran terhadap kebersihan lingkungan meningkat. Melaporkan hasil kegiatan CSR

berlandaskan konsep Tri Hita Karana yang telah dilakukan selama satu periode, karena dengan hasil ini akan menghasilkan bahwa kegiatan CSR berlandaskan konsep Tri Hita Karana akan lebih 
efektif dan efisien dilakukan pada periode berikutnya. Penelitian selanjutnya menggunakan teknik dan perusahaan yang berbeda untuk mendapatkan informasi yang lebih lengkap.

\section{DAFTAR PUSTAKA}

Alihamdan. (2017). Apa yang Dimaksud Dengan Implementasi? Retrieved from https://www.alihamdan.id/ implementasi/

Bardos, K. S., Ertugrul, M., \& Gao, L. S. (2020). Corporate social responsibility, product market perception, and firm value. Journal of Corporate Finance, 62, 101588. doi:10.1016/j.jcorpfin.2020.101588

Gursoy, D., Boğan, E., Dedeoğlu, B. B., \& Çalıskan, C. (2019). Residents' perceptions of hotels' corporate social responsibility initiatives and its impact on residents' sentiments to community and support for additional tourism development. Journal of Hospitality and Tourism Management, 39, 117-128. doi:10.1016/j.jhtm.2019.03.005

Hadi, N. (2011). Corporate Social Responsibility (CSR) (1st ed.). Jakarta: Graha Ilmu.

Sri Ardani, N. K., \& Mahyuni, L. P. (2020). Penerapan Corporate Social Responsibility (CSR) dan Manfaatnya Bagi Perusahaan. Jurnal Manajemen Bisnis, 17(1), 12. doi:10.38043/jmb.v17i1.2339 